\title{
『特集』論説／都市再生と環境配慮
}

\section{土地価格概念の立体化と都市空間の集約利用 Right transformation that used three-dimensional land value}

Yasuhiro NAKAJO : Meikai University

中城 康彦*

The bipolarization of the land price is going on. To prevent the decline of the land price, the landowner desires to cancel the defect of the land. The defect of the land can be canceled by the joint building. The right transformation is necessary for the implementation of the joint building. In the urban region the land value is the worth of the solid. We can do right transformation fairly, by using the three-dimensional land value.

keywords : income approach, air right, joint building, right transformation 収益還元法, 空中権, 共同ビル方式, 権利変換

\section{1. 土地の収益性と地価の 2 極化}

地価の 2 極化が顕著である。継続的な地価下落 状況のなか，利用価值が高いものは相応に評価さ れる一方，これに劣るものは大幅に地価を下落さ せる傾向が強まっている。不動産の価格が収益性 を重視して決定されるようになっていることから すれば，従来省みられることの少なかった収益性 の差異が地価として顕在化しつつあると指摘でき る。

\section{1 -1 地価の立体性}

地価公示や相続税路線価等の報道に際して,「夕 夕ミ 1 枚分がいくら」に相当すると，土地価格を わかりやすく表現することがある。土地価格を地 面という平面 -2 次元一として把握し, それを単 位面積あたりで表現することが当然のことのよう に行われて, 土地価格 $=$ 単位面積あたり単価 $\times$ 平 面積と理解された。農業的土地利用や青空駐車 場など，平面的土地利用を前提にするならばこの
理解は妥当する。しかしながら，中高層建築物を 建築する都市的土地利用を前提とする場合, 地価 は平面では説明することはできない。都市的土地 利用において, 土地の価值とは土地上に複数層の 建築物を建築して立体的に利用することによって 得られる空間の価値にほかならず，地価とはこの 空間価值を集計した便宜上の数值に過ぎない。都 市的土地利用において地価とは空間価值であり， 立体 -3 次元一でとられるべきもので, 土地価格 =単位体積あたり単価 $\times$ 立体積 と理解されるべ きである。

\section{1-2 収益の不連続性}

地価の 2 極化とは, とりもなおさず, 平面積重 視においては潜在下にあった収益性の優劣が立体 積重視において顕在化するようになったことにほ かならない。以下において，地価の 2 極化につい てモデルで検討する。

1-2-1 モデルの想定

図表一 1 のとおり隣接 4 画地を敷地として建築 
物を想定し，その賃料収入を資本還元することに より土地（空間）の収益価格を求める。土地の所 有権は法令上の制限内においてその上下に及ぶ （民法第207条）が，ここでは法令上の制限として 主に都市計画法抢よび建築基準法を念頭におきそ の制限を考慮した。収益還元式は直接還元式 ${ }^{1}$ を 採用するほか，簡単のために，以下を前提とし た2。

直ちに収益可能な状態にあるものとする。

建物賃貸借以外の賃料収入・使用料収入は考 虑しない。従って、全ての収入は賃貸専用面積 に転稼する。

図表ー2 画地Aの空間価値

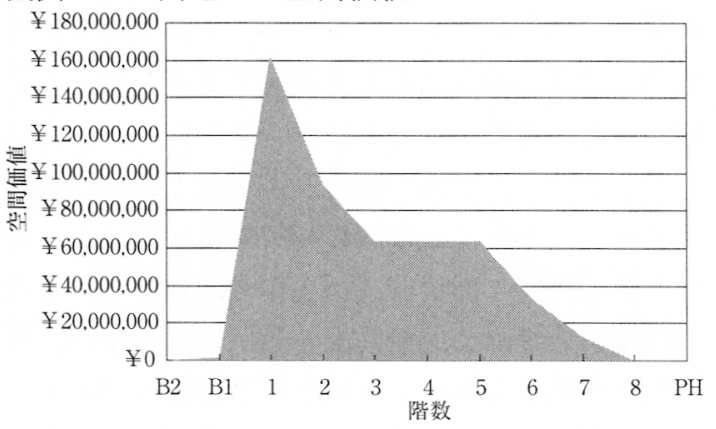

図表ー4 画地 Cの空間価值

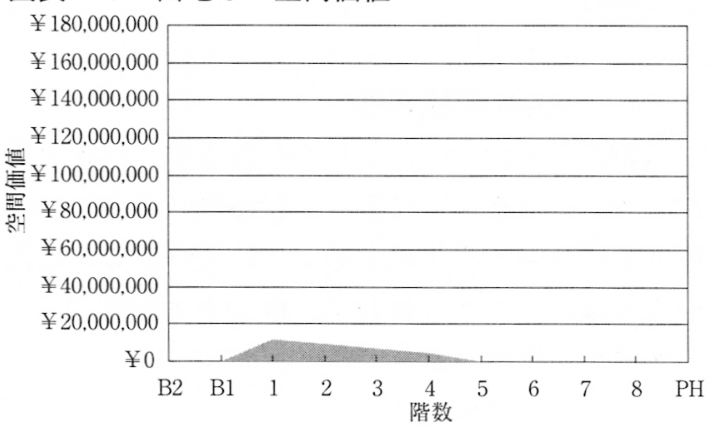

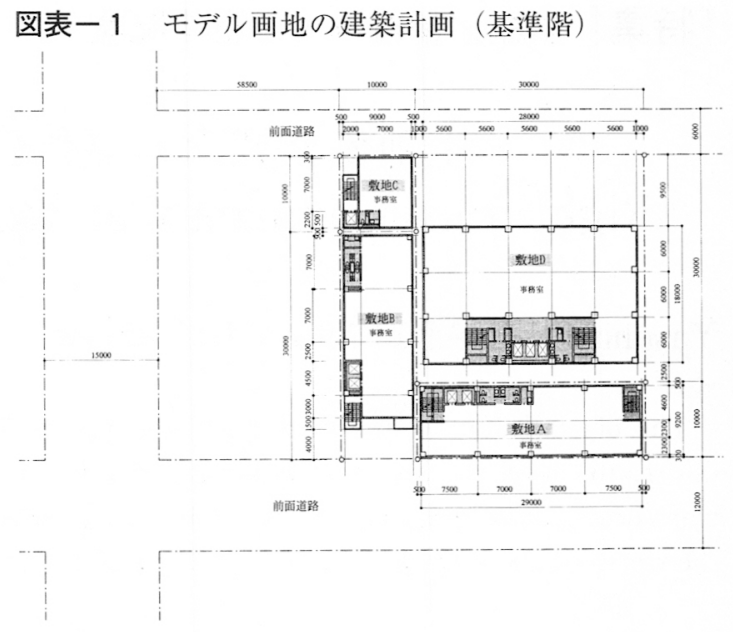

図表一 3 画地 B の空間価值

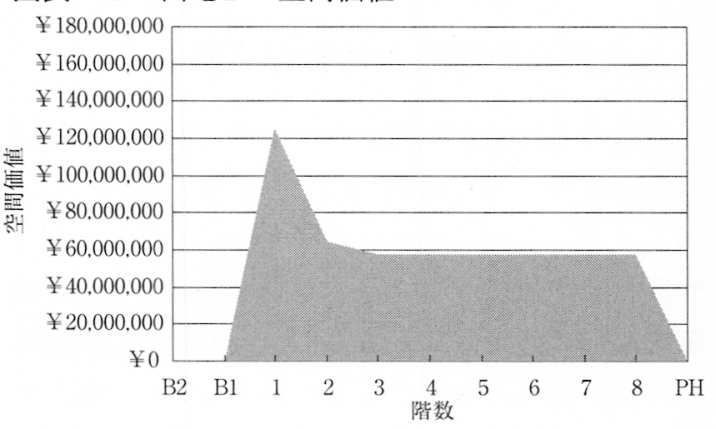

図表－5 画地 Dの空間価値

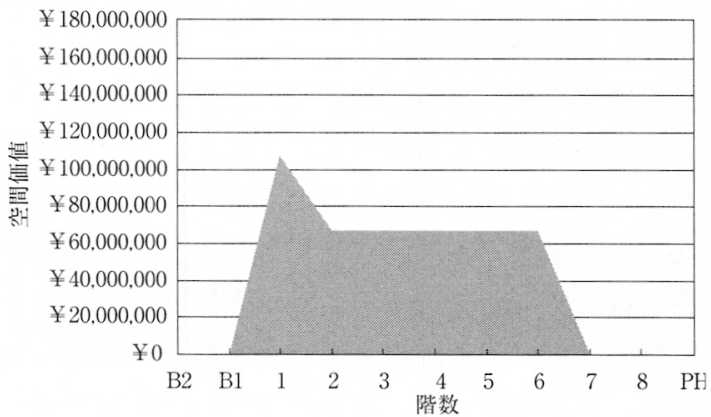

${ }^{1}$ 不動産の純収益（a ）を当該不動産の還元利回り（r）で還元する（P=a/r)。収益還元は土地残余法により，これを立 体的に適用して空間の価值を直截的に求める。

2 本稿の目的は収益還元手法ごとの妥当性を議論するものではないので，極力単純な還元式を用いた。 
$\bigcirc$ 各棟間の建築費, 貢料単価は想定した地域の

一般的な格差を採用する。

1-2-2 収益格差の実態

モデルにより求めた空間価值を図表 - 2 図表 - 5 に示す。グラフは各敷地の階層ごとの空間価 值を示すと同時に，色づけした部分の面積は空間 価值の合計として，いわゆる土地価格を示してい る。4 画地ともに特徴的な空間価值の分布状態を 示して興味深い。空間価値の分布状態はいくつか にパターン化できることを示唆しているように思 える。

図表- 6 は, 敷地面積と土地単価の関係を示し たものであるが，収益性の不連続に関して，以下 の 2 点を指摘できる。

(1) 画地 $\mathrm{A}$ と画地 $\mathrm{B}$ とは, 間口と奥行の関係で一 般的には画地 Aの価值が高いと考えられている (+5\%〜+20\%程度）が，収益性からみれば，少

\section{図表一 6 収益価格の分布}

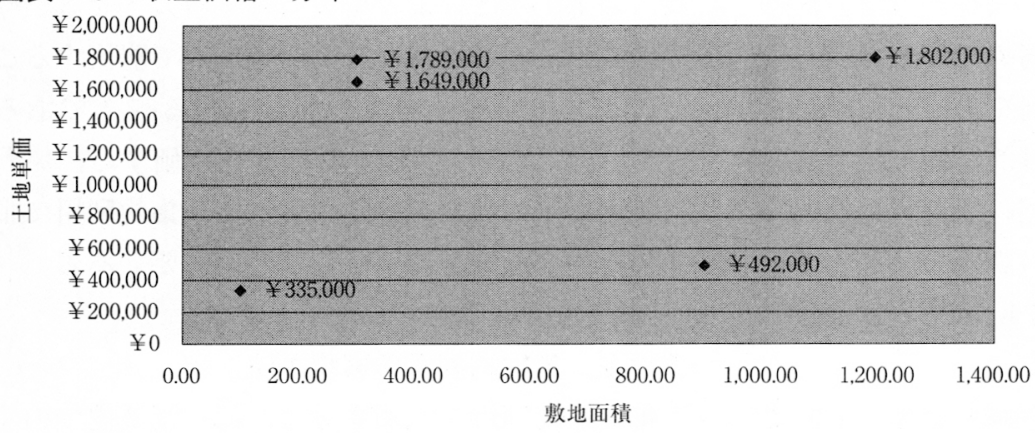

\begin{tabular}{|c|c|c|c|c|c|}
\hline & 画地A & 画地B & 画地C & 画地D & 画地 A ・ D \\
\hline 敷 地 面 積 $\left(\mathrm{m}^{2}\right)$ & 300.00 & 300.00 & 100.00 & 900.00 & $1,200.00$ \\
\hline 前面道路幅員 (m) & 12.00 & 12.00 & 6.00 & 6.00 & 12.00 \\
\hline 基準容積率（\%) & $600.00 \%$ & $600.00 \%$ & $367.71 \%$ & $419.14 \%$ & $600.00 \%$ \\
\hline 空間価值合計（円） & $¥ 494,575,230$ & $¥ 536,766,286$ & $¥ 33,451,421$ & $¥ 442,669,637$ & $¥ 2,161,931,883$ \\
\hline 土地 単 価 $\left(\right.$ 円 $\left./ \mathrm{m}^{2}\right)$ & $¥ 1,649,000$ & $¥ 1,789,000$ & $¥ 335,000$ & $¥ 492.000$ & $¥ 1.802,000$ \\
\hline 単 価 指 数 (\%) & $100.00 \%$ & $108.49 \%$ & $20.32 \%$ & $29.84 \%$ & $109.28 \%$ \\
\hline
\end{tabular}

\section{3 主要構造部が準耐火構造等の建築物の場合}

4 避難バルコニー等を併設する必要がある。

5ソーシャルビルといわれることがある。

${ }^{6}$ 画地 Bにおいては道路斜線制限は問題とならないが，画地 Aにおいては建築物の形状に大きく影響することもこの差異の 一因である。
なくともこのケースについては逆転する。顀料単 価は画地 Aを高く設定していることからすれば, この結果は，延べ面積に対する賃貸有効率の差異 に依存している。

小規模ビルにおいては避難階段の設置方法と賃 貸有効率との関連はことのほか大きい。建築基準 法施行令に直通階段を設ける場合について規定が あり 2 方向避難の確保のためには 2 以上の直通階 段を設けることが原則となるが，事務所ビルで居 室の床面積が $200 \mathrm{~m}^{2}$ を超えない場合は ${ }^{3}$, 屋外避難 階段 1 ケ所でよい 4 との緩和規定がある（建築基 準法施行令121条 1 項 5 号)。ペンシル型の飲食店 舗ビル ${ }^{5}$ などにおいて採用されることの多い建築 方法である。

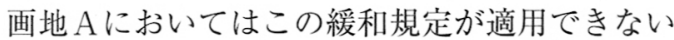
ために，避難階段を２ケ所設置したが，画地 Bに おいては，緩和規定を適用した。このために，賃 貸有効率は前者において $73.02 \%$ ，後者において $78.95 \%$ となった ${ }^{6}$ 。当該 規定の結果，一定の敷地 規模において収益性に不 連続が発生し，狭小敷地 の利用効率を高めている 側面がある。

(2) 画地 $\mathrm{A}$ 画地 $\mathrm{D}$, 画 地 $\mathrm{B}$ 画地 $\mathrm{C}$ は隣接する 土地であるものの，その 収益性には大きな差異が ある。画地 $\mathrm{A}$ と画地Dの 土地単価比は100:30であ るが, この格差は, 従来 
図表-7 敷地集約と空間価值の変動

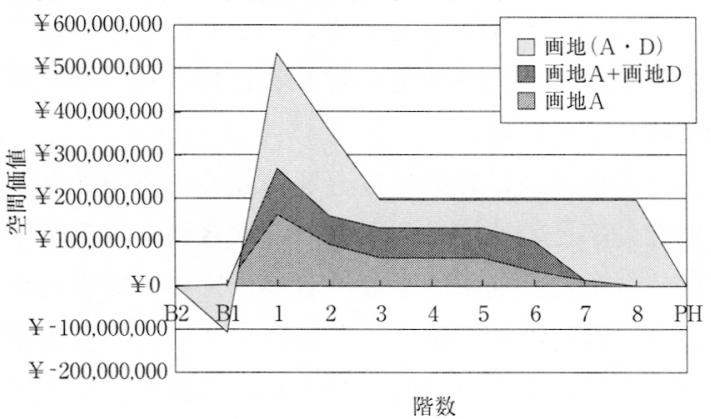

一般に考えられてきた格差に比較して相当に大き い。7

当該格差は, 道路幅員がもたらす通行上の利便性・ 効率性の差異よりはむしろ, 基準容積率の差異 8 に依存している。

\section{$1-3$ 敷地集約の有利性}

地価の 2 極化, 換言すれば, 収益性の差異の土 地価格への顕在化は, 一方で, 収益性の阻害要因 を解消するインセンティブを高めているといえる。 木造低層建築物による土地利用を前提として細分 化された土地利用区分が，今日的な都市的土地利 用に対応できないことがわが国の都市問題の根幹 にある。その集約は都市再生の課題のひとつであ るが，集約による経済的利益を明示することはそ の促進に重要であると指摘したい。

図表一 1 に拈いて, 画地 $\mathrm{A}$ と画地 D とを集約化 して 1 敷地 ${ }^{9}$ として建築することを想定した（以

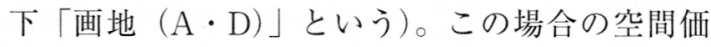
值と画地 $\mathrm{A}$ ，画地 $\mathrm{D}$ それぞれ単独の場合の空間価 值をグラフ化したものを図表-7に示す。地下駐 車場が空間価值を負とする地下 1 階を除いて全て
の階で画地（A・D）の空間価值が上回っており， 総量（土地価格)では，231\%となり，131\%の集約 化利益を発生させることがわかる。地価が続落す るなかで，利用区分を見直すことによってもたら されるこの収益性の改善はその実現のための困難 を考慮してもなお，十分に魅力ではある。

地価の続落によって集約化の障壁が相対的に低 下しており，今後多様な形態をとりながら集約が 進展するものと考えられる。このため, 敷地集約 がもたらす社会的・経済的利益について啓蒙する, 集約を容易に実践できる公平なシステムをつくる， より社会性を持たせ都市環境など今日的課題に貢 献する集約オプションを設ける，などが要請され ている。

\section{2 利用と環境の共存}

土地利用の増進は，当該土地の資産価值を高め る効果がある半面, 緩和された増床分だけ二酸化 炭素の排出などにより環境負荷を増大させる。今 後はこのような外部不経済を敷地内で解決するこ とにより，利用と環境の共存を図るべきであろ う ${ }^{10}$ 。この課題に貢献する程度を評価する，いわ ば集団規定の性能規定化によって, 集約利用によ り積極的な意味を持たせることが必要である。

\section{2-1 集約的利用の実現手法}

集約的な利用を大別すると，同一敷地内での集 約と，異なる敷地間での集約とに区分できるが, 公法としての都市計画法や建築基準法の規制・誘 導を実現するために，私法上の調整が必要となる ことに特徵と困難がある。

\footnotetext{
7 背後の敷地の価格割合として $60 \%$ 程度がひとつの目安であったように思われる。

8 建築基準法第52条 1 項。

9 敷地の集約化はただちに権利の集約化（売買による所有権の移転等）を意味すものではない。

10増床分だけ多くの建物固定資産税を納税することとなるが，今日的に固定資産税は，道路等の人工的インフラに対する負 担との意味合いにとどまっている。
} 
2-1-1 敷地内集約 - 共同ビル手法

所有権を留保したまま共同で建築する共同ビル 方式は敷地集約による高度利用の典型である。共 同ビル事業11は, 都市再開発法にもとづく市街地 再開発事業の権利変換手法に準じて, 専門のコン サルタントによって誘導されることが通常であ る ${ }^{12}$ 。権利変換手法は，事業に提供する従前資産 と取得する従後資産の額が一致するように行うこ とが原則であり，敷地集約による上記のような集 約利益をどのように各権利者に配分するかが課題 となる。権利変換は個別のケースごとに専門家の 判断によって処理されているのが実態であるが, 集約化を適切に促進するとの観点からはより簡便 化された指標やシステムが並存することが必要で ある。

区分所有マンションの建替えに際して権利変換

図表－8 区分所有マンションの価值比の例

\begin{tabular}{|c|c|c|}
\hline 階 & $\begin{array}{l}3 \text { 階の標準 } \\
\text { 的な住戸 } \\
\text { を基準とし } \\
\text { た場合の } \\
\text { 洒值指数 }\end{array}$ & $\begin{array}{l}3 \text { 階の最も } \\
\text { 安価な住 } \\
\text { 户を基準と } \\
\text { した場合の } \\
\text { 価值指数 }\end{array}$ \\
\hline 32 & $149 \%$ & $169 \%$ \\
\hline 30 & $146 \%$ & $166 \%$ \\
\hline 28 & $121 \%$ & $137 \%$ \\
\hline 26 & $120 \%$ & $136 \%$ \\
\hline 24 & $119 \%$ & $135 \%$ \\
\hline 22 & $118 \%$ & $134 \%$ \\
\hline 20 & $116 \%$ & $133 \%$ \\
\hline 18 & $115 \%$ & $131 \%$ \\
\hline 16 & $114 \%$ & $129 \%$ \\
\hline 14 & $112 \%$ & $128 \%$ \\
\hline 12 & $111 \%$ & $126 \%$ \\
\hline 10 & $110 \%$ & $125 \%$ \\
\hline 8 & $103 \%$ & $118 \%$ \\
\hline 6 & $102 \%$ & $116 \%$ \\
\hline 4 & $101 \%$ & $115 \%$ \\
\hline 3 & $100 \%$ & $114 \%$ \\
\hline
\end{tabular}

手法を用いることが提案されている。区分所有建 物は, 既存建物の価值 (図表-8) と敷地持分 ${ }^{13}$ の間に差異があることが多い，建替え後の区分所 有建物の価值が階層や方位によって大きくことな る，など権利変換を困難にする要因がある。すみ やかに専用の権利変換理論を構築する必要がある。 $2-1-2$ 敷地間集約 - 容積移転手法

敷地の区分はそのままに，より高度利用を希望 する者とそうでない者との間で利用権を調整する 方法も実現可能性が高まっている。連担建築物設 計制度 ${ }^{14}$ や特例容積率適用区域制度 ${ }^{15}$ はその例で ある。

米国で行われているTDRでは空中の利用権を 個人の財産権として認め, これを譲渡するという 構成であるのに対して，容積率は公的な規制に係 る規制值であり，容積そのものが売買の対象とな ることはないとされる。つまり,「実質的な敷地間 の容積移転の効果を発生させることも事実だか, 特定行政庁が，余剩の容積を利用する権利の売買 契約などの関係権利者の個別の実情について審査

図表ー 9 街並み誘導型地区計画による空間価値の 上昇

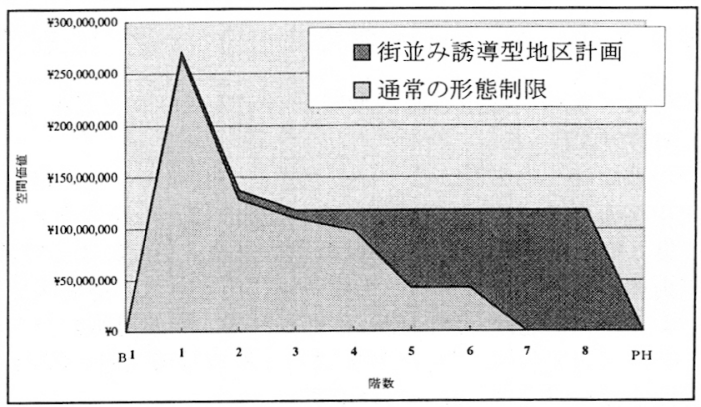

\footnotetext{
11建物の所有形態からは, 共有もしくは区分所有となる。通常は区分所有となることから,「区分所有方式」と表現するこ ともできる。

12中城康彦「不動産コンサルティングのための共同ビル計画の誘導」『不動産鑑定』1988住宅新報社通巻314-316

13敷地の共有持分は専有面積比によることが通常。『マンション管理の知識』住宅新報社2001年 8 月p 149

14平成10年建築基準法改正により創設。

15平成12年都市計画法改正により創設。
} 
するものではなく，余剩の容積を利用する権利の 売買を制度的に認めるものではない」16ために, 容 積移転対価の算定という私法上の解決が必要であ る。立体の利用権の一部たる容積移転の対価算定 の査定式を標準化して公表することにより，当該 制度の適切な運用が図られるべきである ${ }^{17} 。$

2-1-3 立体価値查定式による空間価值イン デックス

図表 -7 は敷地集約による空間価值の変化を示 すものであるが, 敷地内集約の権利変換はこのプ ロセスを追跡することに他ならない。空間価值の 分布状態を把握することで権利変換は大幅に簡易 化することができる。立体的な価值分布をイン デック化することで, 敷地間集約の場合に必要な 私法上の解決も容易となろう ${ }^{18}$ 。

\section{2-2 集約利用と都市環境}

2-1-4 規制緩和と空間価値

空間の利用を制限する規制の緩和は一般に利用 価值を高め, 資産性を上昇させる。ここでは, 東 京都中央区が導入している街並み誘導型地区計画 を例 ${ }^{19} に$, 規制緩和と空間価値の関係を見る（図 表-8)。空間価值の差異は, 低層部では皆無と いってよいが, 中高層階では相違が顕著で, 総額
で163\%となっている 20 。こ差異の源泉は, 前面 道路幅員による容積率制限および道路斜線制限の 適用除外が主たるものである。

\section{2-1-5 集約利用の積極的課題}

利用と環境の共存を志向する古典的な規制緩和 制度に総合設計制度と総合的設計制度がある。総 合設計制度は敷地規模要件にもとづき敷地内の公 開空地率に応じて容積率の割増を行うほか斜線制 限を緩和するもので敷地内環境改善に貢献するこ とができる ${ }^{21}$ 。制度上，市街地の環境の改善に対 する総合的な配慮が求められるが, 交通上, 安全 上，防火上の支障の有無が検討されるにとどまっ ている。今日的な都市環境の課題からは公開空地 の定義を多様化 $22 し$, 環境上の貢献に応じて緩和 を考慮するように改めるとともに，その考えを任 意の敷地集約事業に敷衍すべきであろう。

総合的設計制度は, 1 建築物 1 敷地の原則に対 する例外として，1団地内の複数建築物に関する 特例対象規定 ${ }^{23}$ 適用については同一敷地内にあ るものとみなすもので, 敷地間環境改善に貢献す ることができる。連担建築物設計制度の創設によ り，棟ごとの建替えが容易になったことでもあり， 積極的に適用を認めるべきである。この場合, 安 全上，防火上および衛生上の要件に加えて，環境

\footnotetext{
${ }^{16}$ 建設省都市局都市計画課他監修『平成12年改正都市計画法・建築基準法の解説 Q \& A』株式会社大成出版社 2000 年 7 月 p117.p119

${ }^{17}$ 中城康彦「都市計画法・建築基準法の改正と土地価格の考え方」『季刊用地』2001夏季号VOL. 02NO. 004p54.p55 ${ }^{18}$ 中城康彦「連担建築物設計制度の創設にともなう立体地価インデックスの必要性とその考え方」『明海大学不動産学部論 集』第 7 号1999年 3 月。「連担建築物設計制度による空間の利用と価值」『明海大学不動産学部論集』第 8 号2000年 3 月。 ${ }^{19}$ 街並み誘導型地区計画は平成 7 年に創設され, 中央区では平成 9 年以降導入している。ここでは, 銀座 6 丁目の A 地区に よった。敷地は, 間口 $18 \mathrm{~m} \times$ 奥行 $18 \mathrm{~m}$, 前面道路幅員 $7 \mathrm{~m}$ (歩道なし), 指定容積率 $700 \%$ 。前面道路幅員による容積率の 緩和 (適用除外), 道路斜線制限・隣地斜線制限の緩和（適用除外）のほか, 機能更新型高度利用地区との併用による容 皘率緩和が受けられる場合がある。

20地価公示においてこのような変動は必ずしも顕在化していない。その理由は, 地価公示価格は収益価格だけで決定するも のではない，当該地区計画のようにその適用が任意のものについては原則としてこれを考虑しない，ことによる。

${ }^{21}$ 中央区導入の街並み誘導型地区計画は環境配慮等の要件はほとんどないといってよい。地域的な限定により運用されるべ きであろう。

22単にオープンスペースとしての平面積によるのではなく, 壁面や屋上を含む緑のボリュームを考虑する。また, 免震構造 や非常用飲食料の備蓄といった防災上の観点についても性能評価する。

${ }^{23}$ 接道規定, 容積率制限, 建蔽率制限, 外壁後退, 斜線制限, 日影規制等。
} 
上の貢献を積極的に位置付け，より小集団の建築 群にも適用すべきであろう。郊外部においては道 路率の低下による区画整理事業の事業性の向上, 行き止まり道路によるミニ乱開発の抑制にも貢献 可能である。

\section{3 まとめ}

わが国の都市はすでに相当に巨大であり，広域
的には指定容積率は十分に使いこなされていない 程度に緩やかである。また，都市環境問題の深刻 化が懸念されてもいる。ここでは，都市の再生を 更なる規制緩和という視点ではなく，現行制度内 での集約的利用の観点から検討した。集約による 空間価值の増加は十分に大きいものである。その 実現を支援するとともに，集約を契機付ける環境 志向型の建築規定を導入すべきである。 